大量 $\gamma$ グロブリン療法にて血小板増加が得られ安全に手術が施行された MDS の 1 例

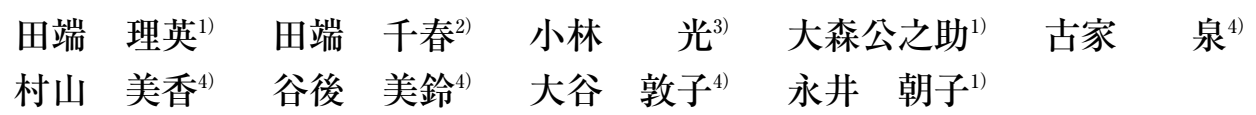

今回われわれは大量 $\gamma$ グロブリン療法（IVIG）にて血小板増加が得られ，大量出血が予想される大腿骨頸部内側 骨折に対する人工骨頭置換術が少量の出血のみで施行された高齢者骨髄異形成症候群（MDS）を経験した．本例は MDS のうち不応性貧血（RA）に合致するが, PAIgG が著明高值を示しており, 初回治療時にステロイドおよび免 疫抑制剂に対する良好な血小板増加反応がみられていた。また直接クームス試験（DAT）は陰性ながら，この免疫 抑制療法により初診時に認められた高度の貧血も改善がみられ，本症例においては貧血拉よび血小板減少の原因と して, 分化異常に加えて自己免疫機序の関与が示唆された．ただ，術後 1 週間に健側下肢に深部静脈血栓症 (DVT) が発生し,これに IVIG が関与した可能性が否定できない. MDSに扔ける自己免疫性血小板減少症に IVIG 療法は有 用であると思われるが，DVTのリスクのある患者には慎重投与が必要である.

キーワード : 大量 $\gamma$ グロブリン静注療法，骨髄異形成症候群

\section{はじめに}

大量 $\gamma$ グロブリン静注療法（IVIG）は，特発性血小 板減少性紫斑病（idiopathic thrombocytopenic purpura：ITP)の手術や出産などの際に, 急速に血小板を 上昇させる目的にて広く施行され，その有用性が知ら れている，今回われわれは，低形成性骨䯣で巨核球の 減少を伴うものの, PAIgG が著明高值を呈し，初発時 の著明な血小板減少に対して免疫抑制療法が有効であっ た骨髄異形成症候群（MDS）の高齢者に扔いて，血小 板著減の再発時に, 大腿骨頸部内側骨折に対する人工 骨頭置換術を,術前のIVIG 施行により速やかかつ安定 した血小板増加が得られ，大量出血することなく安全 に施行できた症例を経験した。

\section{症例}

79 歳女性.

【主 訴】 労作時呼吸困難, 紫斑.

【既往歴】 72 歳より糖尿病にて近医でインスリン治療 中.

【現病歴】平成 17 年 9 月他院にて血小板（PLT）減 少 (0.9万)のため入院治療を受けていた(詳細不明)が,
退院後放置. 平成 18 年 3 月初旬より歩行時息切れ，紫 斑が出現し，近医より貧血，PLT 減少のため紹介され 入院となった。

【人院時検查所見】入院時検查所見を Table 1 に示す. 著明な貧血と血小板減少を認めるが，白血球数掞よび 分画には異常を認めなかった。 また網状赤血球増加と PAIgG 著増を認めた。直接クームス試験 (DAT) は陰 性であった. D-D および LDH の若干の上昇以外には凝 固系や生化学検查において異常を認めず，免疫グロブ リン，甲状腺機能も正常であった，尿素呼気試験にて ヘリコバクターピロリ感染が確認された．腸骨骨髄穿 刺による骨髄所見では, クロット標本にて造血細胞域 が 20 30\% の低形成骨髄で脂肪が増加し，その造血細 胞域において, 腫瘍細胞の増加は認められなかった(Fig. 1A).巨核球はカウント上 0 であったがスメアでは数個/ 枚みられ, 芽球の増加はなく, 3 血球系統に異型が認め られた（Fig. 1B〜E). 染色体は正常核型であった.

【経 過】骨髄穿刺にて MDS-RA と診断し，著明な PLT 減少については PAIgG 著明高值であり, 自己免疫 機序の関与を考え, ステロイド(プレドニゾロン $[\mathrm{PSL}]$ $30 \mathrm{mg} /$ 日) 投与を行ったところ PLT 上昇反応がみられ

\footnotetext{
1）兵庫県立塚口病院内科

2) 兵庫医科大学内科学 $\cdot$ 呼吸器 RCU 科

3）小野市立小野市民病院整形外科

4）兵庫県立塚口病院検查・放射線部
}

〔受付日：2008 年 7 月 14 日，受理日：2009 年 3 月 27 日〕 
Table 1 Laboratory findings at admission

\begin{tabular}{|c|c|c|c|c|c|}
\hline WBC & $5,500 / \mu l$ & GOT & $20 \mathrm{IU} / l$ & IgG & $931 \mathrm{mg} / \mathrm{d} l$ \\
\hline Seg & $79.0 \%$ & GPT & $12 \mathrm{IU} / \mathrm{l}$ & $\operatorname{Ig} A$ & $304 \mathrm{mg} / \mathrm{d} l$ \\
\hline Lym & $16.0 \%$ & ALP & $273 \mathrm{IU} / \mathrm{l}$ & $\operatorname{IgM}$ & $59 \mathrm{mg} / \mathrm{d} l$ \\
\hline $\mathrm{RBC}$ & $190 \times 10^{4} / \mu l$ & $\gamma \mathrm{GTP}$ & $14 \mathrm{IU} / l$ & $\mathrm{C} 3$ & $91 \mathrm{mg} / \mathrm{d} l$ \\
\hline $\mathrm{Hb}$ & $5.3 \mathrm{~g} / \mathrm{d} l$ & LDH & $333 \mathrm{IU} / l$ & $\mathrm{C} 4$ & $13 \mathrm{mg} / \mathrm{d} l$ \\
\hline Ret & $6.8 \%$ & $\mathrm{TC}$ & $158 \mathrm{mg} / \mathrm{d} l$ & ANA & $<40$ \\
\hline Plt & $0.2 \times 10^{4} / \mu l$ & TG & $171 \mathrm{mg} / \mathrm{d} l$ & CH5O & $54.0 \mathrm{U} / \mathrm{ml}$ \\
\hline $\mathrm{PAIgG}$ & $949.5 \mathrm{ng} / 10^{7} \mathrm{PLT}$ & BUN & $20.6 \mathrm{mg} / \mathrm{d} l$ & Urease test & $3.4 \%$ \\
\hline PT & $86 \%$ & UA & $3.5 \mathrm{mg} / \mathrm{d} l$ & Vitamin $B_{12}$ & $380 \mathrm{pg} / \mathrm{ml}$ \\
\hline APTT & $21 \mathrm{sec}$ & $\mathrm{Cr}$ & $0.65 \mathrm{mg} / \mathrm{d} l$ & Haptoglobin & $27.4 \mathrm{mg} / \mathrm{d} l$ \\
\hline Fib & $223 \mathrm{mg} / \mathrm{d} l$ & TP & $6.3 \mathrm{~g} / \mathrm{d} l$ & DAT & $(-)$ \\
\hline D-D & $6.31 \mu \mathrm{g} / \mathrm{ml}$ & Alb & $3.8 \mathrm{~g} / \mathrm{d} l$ & F-T4 & $0.83 \mathrm{ng} / \mathrm{ml}$ \\
\hline $\mathrm{Fe}$ & $67 \mu \mathrm{g} / \mathrm{d} l$ & CRP & $0 \mathrm{mg} / \mathrm{d} l$ & TSH & $0.79 \mu \mathrm{IU} / \mathrm{ml}$ \\
\hline UIBC & $314 \mu \mathrm{g} / \mathrm{d} l$ & $\mathrm{HbA}_{1} \mathrm{C}$ & $7.6 \%$ & & \\
\hline
\end{tabular}

たが，5～6万台にとどまった，ピロリ菌が陽性であっ たので，除菌を行うとともに，高齢であること，糖尿 病でインスリン療法中であることより，すみやかなス テロイド減量がのぞましいため, アザチオプリン $(\mathrm{AZ})$ $50 \mathrm{mg} /$ 日の併用を行ったところ, 著明な PLT 上昇が得 られ, PSL の減量が可能であった（Fig. 2A).

外来にて AZを中止するとともに PSL を漸減したが, PLT 值は 13〜14万と安定し，PSL2mg/日で維持して いたところ, 初回入院より 1 年 4 カ月後に突然点状出 血をきたすようになり，平成 19 年 7 月 PLT0.2万と著 減したため再入院となった. 再入院時の検查結果を $\mathrm{Ta}$ ble 2 に示す. 著明な PLT 減少と PAIgG 高值を認める が，貧血は軽度であった，入院時出血症状が著明なた め, PC 輸血を行うとともに, PSL2mg/日から $30 \mathrm{mg} /$ 日へ増量した。

入院以降 PC 輸血後 2 3 日で PLT 值が輸血前值まで 減少するという一時的効果しかなく，またPSL30mg/ 日への増量および AZ50mg/日の併用投与により徐々に PLT3〜4万まで上昇したが，さらなる増加が得られな かったため, 追加の免疫抑制療法を検討していた第 21 入院病日，転倒して左大腿骨頸部内側骨折を認めた。 完全転位型 (Garden IV) の骨折で骨接合術が困難なた め, 人工骨頭置換術が必要となった。高齢者の骨折に よる安静臥床時の筋肉萎縮, 活動性低下や認知症を予 防し, 術後の良好な機能回復および早期離床のために, 可能な限り早期の手術が望ましいと考え受傷後 8 日に 手術を施行した，術中の骨切り，髄腔のリーミング, 術中骨折による大量出血の可能性もあり，またそれま で PC 輸血後も安定したPLT 值が維持できなかったた め, 急速かつ安定したPLT 増加を期待して, 手術時の PC 輸血に加え術前のIVIG を行った，手術までに倫理 委員会にはかる時間的余裕がなかったが，倫理委員会 委員長の許可および本人，家族のインフォームドコン セントを取得し, $\gamma$ グロブリン $400 \mathrm{mg} / \mathrm{kg} /$ 日を 3 日間投 与したところ, 投与前 PLT 4.4 万から投与終了日の翌日
には 10.3 万へ上昇し, 少量の出血にて安全に手術が施 行できた（Fig. 2B).

人工骨頭置換術後 1 週間に右（健側）大腿の浮腫を 認めたため，下肢血管エコーを施行したところ，右膝 窩静脈に $6 \mathrm{~cm}$ にわたる血栓を認めた. ウロキナーゼ 18 万単位/日の持続点滴を 4 日間, 9 万単位/日を 3 日間施 行し，引き続きワーファリン投与を行ったところ，浮 腫の改善が得られた。術後 PSLを減量したが, PLT はさらに徐々に 8〜9万まで上昇し, 退院となった. 以 後外来にてさらにPSL を漸減しつつ経過観察中である.

\section{考 察}

MDS には種々の免疫異常がみられ, polyclonal およ び monoclonal な免疫グロブリン増加や赤血球自己抗体 などが時に認められるが，DAT は，MDS のうち特に 低悪性度群である RA およびRARSに扔いて, 高悪性 度群より高頻度にみられることが報告されている(1) 3)。 今回の症例に押いては DAT 陰性, 抗核抗体除性, 免疫 グロブリン正常で, 負血への自己免疫の関与を示唆す る所見はなかった。しかし, 初回入院時認められた著 明な貧血が免疫抑制療法により改善したことから，貧 血についても自己免疫性溶血の機序の可能性が示唆さ れだ2.

本例では初診時に他の血球に比べ著明な血小板減少 を認めた. PLT の単独減少をもたらす immune thrombocytopenic purpura（ITP）では, 血小板産生の障害 ではなく破壊光進のために末梢血 PLT 減少がもたらさ れると考えられ，通常骨髄巨核球は正常ないし増加し ている，本例では巨核球が減少しており，現在の厚生 労働省の ITP 診断基準に合致しない. しかし, 最近 ITP の血小板寿命が以前考えられていたほど短縮せず，巨 核球産生が低下している症例があると報告された ${ }^{566}$. さらに桑名らにより提唱された, 抗 GPIIb/IIIa 抗体や 血漿 TPO レベルをもとにした新しい ITP 診断基準には 骨髄巨核球数は含まれていない7).一方 ITP は自己免疫 


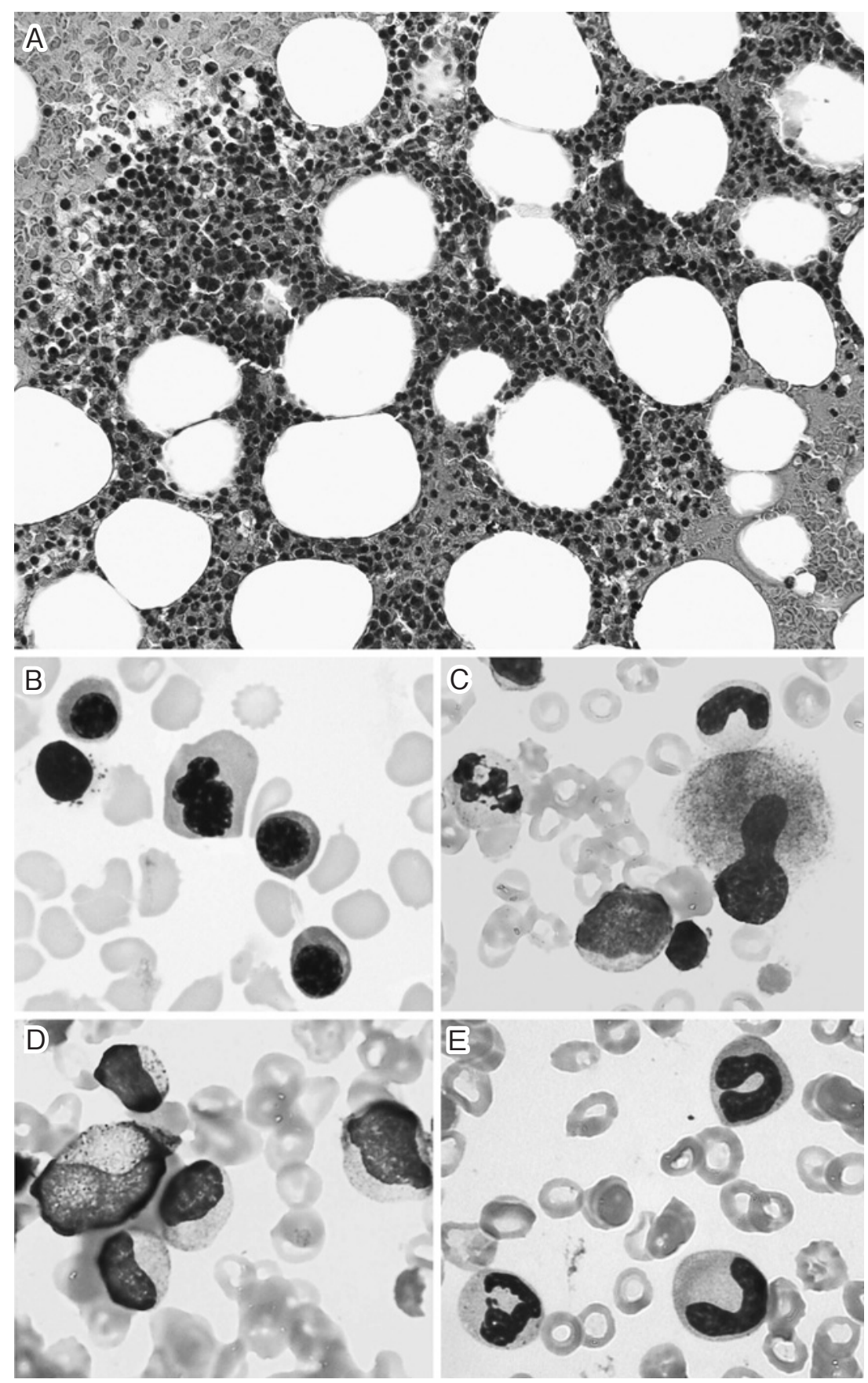

Fig. 1 Bone marrow aspiration revealed fatty marrow with reduced (20-30\%) hemopoiesis in the clot section (A). The smear demonstrated hypocellular marrow (NCC $\left.4.3 \times 10^{4} / \mathrm{mm}^{3}\right)$ with reduced megakaryocytes $\left(0 / \mathrm{mm}^{3}\right)$, containing $0.1 \%$ myeloblasts. The $\mathrm{M} / \mathrm{E}$ ratio was 0.96 . Megaloblastic changes were observed in erythroid cells (B), and megakaryocytes appeared smaller (C). Dysplasia, such as loss of granules, irregularly shaped nuclei, or large cells, were observed in myeloid cells (D, E). Chromosome analysis demonstrated normal karyotype.

性疾患, MDS は clonal な增殖性疾患で両者は全く異な る病態であるが，その鑑別の困難な症例もあり ${ }^{899}$ ，ま たMDS と ITP の合併例 ${ }^{10111)}$ も報告され免疫抑制療法が 有効であったとされている.

一方本症例の腸骨骨髄クロット所見は低形成であり， 高齢者の腸骨骨䯣穿刺では脂肪髄化のために，全体の
骨髄形成性を必ずしも反映していないとはいえ，再生 不良性貧血（AA）との鑑別が困難であった。しかし染 色体異常はみられないものの, 3 血球系統に明らかな異 型を認め, MDS-RA と診断した. 実際に低形成性 MDS と AA には移行例もあるとされ，両者の病態には類似 点もみられる. 特発性 AA の大多数は, 自己免疫的な 
Table 2 Laboratory findings at re-admission

\begin{tabular}{lc|lc|lc}
\hline WBC & $5,800 / \mu l$ & TBIL & $0.4 \mathrm{mg} / \mathrm{d} l$ & ANA & $\times 40$ \\
$\mathrm{RBC}$ & $367 \times 10^{4} / \mu l$ & GOT & $21 \mathrm{IU} / l$ & anti-RNP Ab & $<7.0 \mathrm{U} / \mathrm{m} l$ \\
$\mathrm{Hb}$ & $10.8 \mathrm{~g} / \mathrm{d} l$ & GPT & $11 \mathrm{IU} / l$ & anti-SS-A $/$ Ro Ab $<7.0 \mathrm{U} / \mathrm{m} l$ \\
$\mathrm{Plt}$ & $0.3 \times 10^{4} / \mu l$ & ALP & $204 \mathrm{IU} / l$ & anti-SS-B/La Ab $<7.0 \mathrm{U} / \mathrm{m} l$ \\
$\mathrm{Fe}$ & $108 \mu \mathrm{g} / \mathrm{d} l$ & $\mathrm{LDH}$ & $312 \mathrm{IU} / l$ & anti-TPO Ab & $<0.3 \mathrm{U} / \mathrm{m} l$ \\
$\mathrm{UIBC}$ & $247 \mu \mathrm{g} / \mathrm{d} l$ & $\gamma \mathrm{GTP}$ & $15 \mathrm{IU} / l$ & anti-Tg Ab & $<0.3 \mathrm{U} / \mathrm{m} l$ \\
$\mathrm{RF}$ & $3 \mathrm{U} / \mathrm{m} l$ & $\mathrm{CPK}$ & $56 \mathrm{IU} / l$ & TSH-R Ab & $2.1 \%$ \\
$\mathrm{IgG}$ & $939 \mathrm{mg} / \mathrm{d} l$ & $\mathrm{BUN}$ & $22.7 \mathrm{mg} / \mathrm{d} l$ & PAIgG & $325 \mathrm{ng} / 10^{7} \mathrm{PLT}$ \\
$\mathrm{IgA}$ & $239 \mathrm{mg} / \mathrm{d} l$ & $\mathrm{UA}$ & $3.6 \mathrm{mg} / \mathrm{d} l$ & PR3-ANCA & $<10 \mathrm{EU}$ \\
$\mathrm{IgM}$ & $62 \mathrm{mg} / \mathrm{d} l$ & $\mathrm{CRE}$ & $0.71 \mathrm{mg} / \mathrm{d} l$ & MPO-ANCA & $<10 \mathrm{EU}$ \\
$\mathrm{C} 3$ & $110 \mathrm{mg} / \mathrm{d} l$ & $\mathrm{Na}$ & $135 \mathrm{mEq} / l$ & & \\
$\mathrm{C} 4$ & $14 \mathrm{mg} / \mathrm{d} l$ & $\mathrm{~K}$ & $4.0 \mathrm{mEq} / l$ & & \\
$\mathrm{~F}-\mathrm{T} 3$ & $1.38 \mathrm{pg} / \mathrm{m} l$ & ALB & $4.0 \mathrm{~g} / \mathrm{d} l$ & & \\
$\mathrm{~F}-\mathrm{T} 4$ & $0.83 \mathrm{ng} / \mathrm{m} l$ & $\mathrm{Ca}$ & $9.4 \mathrm{mg} / \mathrm{d} l$ & & \\
$\mathrm{TSH}$ & $0.79 \mu \mathrm{IU} / \mathrm{m} l$ & $\mathrm{CRP}$ & $0.1 \mathrm{mg} / \mathrm{d} l$ & & \\
\hline
\end{tabular}

A

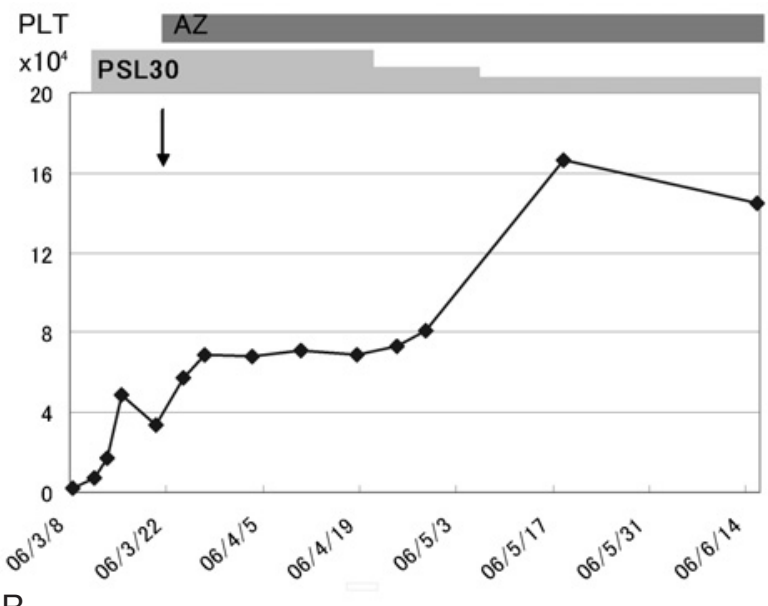

B
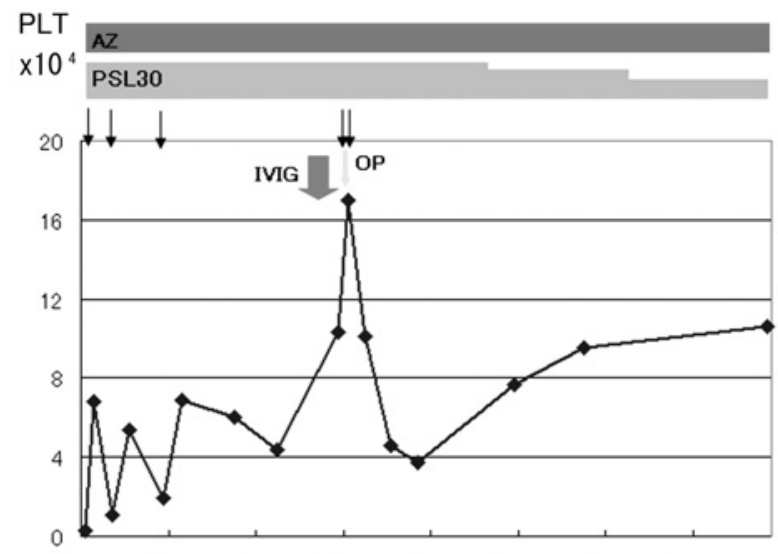

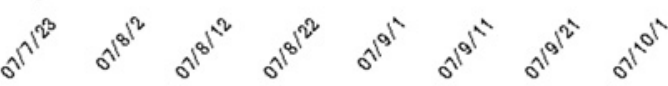

Fig. 2 Clinical course at the first admission (A) and re-admission (B). The arrow in Fig. 2A indicates the elimination of Helicobacter pylori by $60 \mathrm{mg}$ /day lansoprazole, $1,500 \mathrm{mg} /$ day amoxicillin, and $400 \mathrm{mg}$ /day clarithromycin for seven days. Small black arrows indicate transfusion of 10 units of PC.

Abbreviations: AZ, azathioprine; PSL, prednisolone; IVIG, high-dose intravenous gammaglobulin.
機序による造血幹細胞の傷害が原因と考えられており， 治療には免疫抑制療法が有効であり，類似の性格をも つ低悪性度の MDS にも免疫抑制療法が有効な場合があ

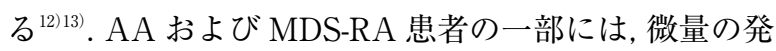
作性夜間血色素尿症（paroxysmal nocturnal hemoglobinuria：PNH）にみられる $\mathrm{PNH}$ 型血球が検出され ることがあり，このような例ではシクロスポリン療法 の有効性が高いことが知られている ${ }^{14)}$.また AAに扔い て DRB1*1501 を有する患者については PNH 型血球が 増加していることが報告されている ${ }^{15}$. 本例においては すでに治療開始後の PLT 上昇時ではあるが, 高感度フ ローサイトメトリー法を用いた PNH 型血球の検出法に て陰性であることが確認され，DRB1*1501 は検索を行 えなかった.一方本例にて抗 DRS-1 抗体打よび抗モ工 シン抗体はいずれも陽性であったが, 抗 DRS-1 抗体や 抗モエシン抗体陽性例では PNH 型血球陰性の場合でも 免疫抑制療法への好反応を示すことが報告され ${ }^{16177}$, 免 疫病態の独立したマーカーとなりうると考えられてい る.

大量 $\gamma$ グロブリン療法（IVIG）は, ITP において, 出血の危険が高い場合や，出産，手術など急速に血小 板増加が必要な場合に施行される。 その作用機序は不 明であるが, 網内系領食能の抑制, 自己抗体の減少な どが考えられている. MDSにおいては, 前述のように 自己免疫の関連が考えられており，本症例のように血 小板減少抢よび貧血が免疫抑制療法にて改善する症例 では, IVIG が有効である場合が少なくないと思われる. ただ, 効果は一過性であり, 高価な治療であるため, その適応については十分に検討する必要がある.

本例では手術後 1 週間で下肢静脈血栓症をきたした が, 整形外科領域の手術に打ける深部静脈血栓症 (DVT) リスク分類では, 股関節全置換術, 膝関節全置換術, 股関節骨折手術が高リスクとされている. 本症例では, 術前にD ダイマーは正常值であり, 肥満, 喫煙歴, 下 
肢静脈瘤や静脈血栓の既往もなく，心エコー，腹部エ コー, 胸部 CT などで DVT リスクを高めるような感染 症, 心不全や他の内科的疾患を認めなかった。 また受 傷前は通常に歩行しており, 受傷後は可能な限りの早 期手術により長期臥床を避け, ギプス固定も行わなかっ た. しかし米国心臟協会の示す DVT の危険因子 8 項目 中 3 項目 (60 歳以上, 整形外科の大手術 (股関節手術 や膝の大手術), 骨盤・大腿骨・脛骨骨折)を満たして いる. 一方 $\gamma$ グロブリンの大量投与の際には, 血液粘度 の上昇等により, 脳梗塞, 心筋梗塞, 肺塞栓症, DVT 等の血栓塞栓症があらわれることがあるので, 血栓塞 栓症の危険性の高い患者においては, 適宜減量し, で きるだけゆっくりと投与することが望ましいとされて いる. 本症例でもその点に留意して $\gamma$ グロブリンを長時 間かけて投与し，また投与終了日から DVT 発症まで 10 日の隔たりがあるが, DVT に IVIG 療法が関与した 可能性は完全には除外できない. MDSにおいて，血小 板減少症に自己免疫性機序の関与が考えられ，特にス テロイドなどの免疫抑制療法に反応良好な症例では, 術前 IVIG 療法が速やかかつ安定した血小板増加に有用 であると考えられるが, 高齢者や長期臥床患者 ${ }^{18) ~ 20}$, 特 に整形外科領域の大手術 ${ }^{21}$ など DVT のリスクのある患 者には，急速輸注による血液粘度の上昇を避けるなど 慎重投与が必要である.さらにPLT 低值のために抗血 栓療法が躊躇され，本症例でも施行しなかったが，出 血症状を観察しつつ, DVT 予防ガイドラインに従って 十分な血栓予防療法が必要と考えられ，今後さらに臨 床的な検討が望まれる.

謝辞 : 筆者らは本例における, 高感度フローサイトメトリー法 を用いた PNH 型血球の検出, 抗 DRS-1 抗体および抗モエシン抗 体発現をご検討いただいた, 金沢大学大学院医学系研究科細胞移 植学 (血液内科) 中尾眞二教授, 杉森尚美先生はじめ教室の先生 方に，深謝申し上げます。

(尚, 本論文の要旨は第 56 回総会日本輸血・細胞治療学会総会 （2008 年 4 月, 福岡）に於けるポスター発表にて発表した）

\section{文 献}

1) Voulgarelis M, Giannouli S, Ritis K, et al: Myelodysplasiaassociated autoimmunity: clinical and pathophysiologic concepts. Eur J Clin Invest, 34: 690—700, 2004.

2) Novaretti MC, Sopelete CR, Velloso ER, et al: Immunohematological findings in myelodysplastic syndrome. Acta Haematol, 105: 1—6, 2001.

3) Barcellini W, Zaninoni A, Imperiali FG, et al: Antierythroblast autoimmunity in early myelodysplastic syndromes. Haematologica, 92: 19—26, 2007.
4) Enright H, Jacob HS, Vercellotti G, et al: Paraneoplastic autoimmune phenomena in patients with myelodysplastic syndromes: response to immunosuppressive therapy. Br J Haematol, 91: 403—408, 1995.

5) McMillan R: The pathogenesis of chronic immune thrombocytopenic purpura. Semin Hematol, 44: S3-11, 2007.

6) Gernsheimer T: Epidemiology and pathophysiology of immune thrombocytopenic purpura. Eur J Haematol Suppl, 69: 3-8, 2008.

7) Kuwana M, Kurata Y, Fujimura K, et al: Preliminary laboratory based diagnostic criteria for immune thrombocytopenic purpura: evaluation by multi-center prospective study. J Thromb Haemost, 4: 1936—1943, 2006.

8) Kuroda J, Kimura S, Kobayashi Y, et al: Unusual myelodysplastic syndrome with the initial presentation mimicking idiopathic thrombocytopenic purpura. Acta Haematol, 108: 139-143, 2002.

9) Sashida G, Takaku TI, Shoji N, et al: Clinico-hematologic features of myelodysplastic syndrome presenting as isolated thrombocytopenia: an entity with a relatively favorable prognosis. Leuk Lymphoma, 44: 653—658, 2003.

10) Park SJ, Han CW, Lee JH, et al: Cyclosporine A in the treatment of a patient with immune thrombocytopenia accompanied by myelodysplastic syndrome and nephrotic syndrome. Acta Haematol, 110: 36—40, 2003.

11) George JN: Idiopathic thrombocytopenic purpura and myelodysplastic syndrome: distinct entities or overlapping syndrome? Leuk Res, 26: 789—790, 2002.

12) Maciejewski JP, O’Keefe C, Gondek L, et al: Immunemediated bone marrow failure syndromes of progenitor and stem cells: molecular analysis of cytotoxic $\mathrm{T}$ cell clones. Folia Histochem Cytobiol, 45: 5-14, 2007.

13) Saunthararajah Y, Nakamura R, Nam JM, et al: HLADR15 (DR2) is overrepresented in myelodysplastic syndrome and aplastic anemia and predicts a response to immunosuppression in myelodysplastic syndrome. Blood, 100: 1570—1574, 2002.

14) Wang $H$, Chuhjo $T$, Yasue $S$, et al: Clinical significance of a minor population of paroxysmal nocturnal hemoglobinuria-type cells in bone marrow failure syndrome. Blood, 100: 3897-3902, 2002.

15) Sugimori $C$, Yamazaki H, Feng $X$, et al: Roles of $D R B 1^{*}$ 1501 and DRB1*1502 in the pathogenesis of aplastic anemia. Exp Hematol, 35: 13—20, 2007. 
16) Feng $X$, Chuhjo $T$, Sugimori $C$, et al: Diazepam-binding inhibitor-related protein 1: a candidate autoantigen in acquired aplastic anemia patients harboring a minor population of paroxysmal nocturnal hemoglobinuriatype cells. Blood, 104: 2425—2431, 2004.

17) Takamatsu H, Feng X, Chuhjo T, et al: Specific antibodies to moesin, a membrane-cytoskeleton linker protein, are frequently detected in patients with acquired aplastic anemia. Blood, 109: 2514—2520, 2007.
18) White RH: The epidemiology of venous thromboembolism. Circulation, 107: I4-8, 2003.

19) Cushman M: Epidemiology and risk factors for venous thrombosis. Semin Hematol, 44: 62-69, 2007.

20) López JA, Kearon C, Lee AY: Deep venous thrombosis. Hematology Am Soc Hematol Educ Program, 439-456, 2004.

21) Schiff RL, Kahn SR, Shrier I, et al: Identifying orthopedic patients at high risk for venous thromboembolism despite thromboprophylaxis. Chest, 128: 3364-3371, 2005.

\title{
IMPROVEMENT IN THROMBOCYTOPENIA BY HIGH-DOSE INTRAVENOUS GAMMAGLOBULIN IN A PATIENT WITH MYELODYSPLASTIC SYNDROME
}

\author{
Rie Tabata ${ }^{1)}$, Chiharu Tabata ${ }^{2)}$, Hikaru Kobayashi ${ }^{3)}$, Konosuke Omori ${ }^{1)}$, Izumi Furuya ${ }^{4)}$, \\ Mika Murayama ${ }^{4)}$, Misuzu Tanigo ${ }^{4)}$, Atsuko Otani ${ }^{4)}$ and Tomoko Nagai ${ }^{1)}$ \\ ${ }^{1)}$ Department of Internal Medicine, Hyogo Prefectural Tsukaguchi Hospital \\ ${ }^{2)}$ Department of Internal Medicine, Respiratory Division, Hyogo College of Medicine \\ ${ }^{3)}$ Department of Orthopedics, Ono Municipal Hospital \\ ${ }^{4)}$ Division of Laboratory and Radiology, Hyogo Prefectural Tsukaguchi Hospital
}

\begin{abstract}
:
We describe a patient with myelodysplastic syndrome (MDS) whose thrombocytopenia was transiently improved by high-dose intravenous gammaglobulin before orthopedic surgery. A 79-year-old woman with MDSrefractory anemia (RA) and complications due to a fracture of the left femur underwent total hip replacement. Platelet (PLT) count, which had improved from $0.2 \times 10^{4} / \mu \mathrm{l}$ to $4.4 \times 10^{4} / \mu \mathrm{l}$ after administration of $30 \mathrm{mg} /$ day prednisolone (PSL), dramatically increased to $10.3 \times 10^{4} / \mu \mathrm{l}$ after administration of gammaglobulin at $400 \mathrm{mg} / \mathrm{kg}$ body weight/day for 3 days. Although the surgery was safely performed with a low volume of bleeding, the patient developed deep vein thrombosis (DVT) of the right popliteal vein. It is well known that patients with MDS occasionally show complications such as various immunological abnormalities and respond to immunosuppressive therapy. In particular, high-dose intravenous gammaglobulin is a potentially useful treatment when a prompt increase in PLT is required. However, prevention of DVT is necessary, particularly in cases with risk factors such as old age, confinement to bed, or orthopedic surgery.
\end{abstract}

\section{Keywords:}

high-dose intravenous gammaglobulin, myelodysplastic syndrome

(C)2009 The Japan Society of Transfusion Medicine and Cell Therapy

Journal Web Site: http://www.yuketsu.gr.jp 